\title{
Reconsidering the motivation of learners in educational computer game contexts
}

\author{
Hakan Tüzün (10 \\ Hacettepe University, Faculty of Education, Ankara, Turkey, htuzun@ hacettepe.edu.tr \\ Sasha A. Barab ${ }^{\circledR}$ \\ Arizona State University, Mary Lou Fulton Teachers College, Tempe, AZ, USA, Sasha.Barab@asu.edu \\ Michael K. Thomas \\ The University of Illinois at Chicago, College of Education, Chicago, IL, USA, micthom@uic.edu
}

\begin{abstract}
The purpose of this study was to identify motivational elements of an online multi-player educational computer game that uses a 3D multi-user environment to immerse children ages 9-12 in educational tasks. The methodological approach design ethnography, a process that involves using ethnographic methods when the researchers are both observers and designers of the context being studied, was employed for researching this game. Interviews were completed with twenty participants playing the educational game and prolonged observations were conducted where participants played the game in a natural setting. The constant comparison method of grounded theory was used for analyzing interview and observation records. The qualitative methods used in this study allowed for additional insights into previous research on motivation. In addition to the 5 constructs identified in previous motivation research on videogames (challenge, curiosity, control, fantasy, and choice), 10 additional motivational elements to play the game emerged from an analysis of interviews with and observations of the 20 children participating in this study. These were identity presentation, social relations, playing, learning, achievement, rewards, immersive context, uniqueness, creativity, and context of support.
\end{abstract}

Keywords: Computer games, Video games, Motivation, Learning, Education

\section{Eğitsel bilgisayar oyunu bağlamlarında öğrencilerin motivasyonu hususunun yeniden incelenmesi}

ÖZ Bu çalışmanın amacı, 9-12 yaş arasındaki çocukları eğitsel görevlere yönlendirmek için üç boyutlu çok kullanıcılı bir ortam kullanan çevrimiçi çok oyunculu eğitsel bir bilgisayar oyununun motivasyonel öğelerini tespit etmektir. Araştırmacıların üzerinde çalışılan bağlamın hem gözlemcisi hem de tasarımcısı olduğu ve etnografik yöntemlerin kullanılmasını içeren bir süreç olan tasarım etnoğrafyası bu oyunu araştırmak için yöntemsel bir yaklaşım olarak kullanılmıştır. Eğitsel oyunu oynayan yirmi katılımcıyla görüşme yapılmış ve katılımcıların oyunu oynadıkları doğal bir ortamda uzun süreli gözlemler yapılmıștır. Görüşme ve gözlem kayıtlarını çözümlemek için temellendirilmiş kuramın sürekli karşılaştırma yöntemi kullanılmıştır. Bu çalışmada kullanılan nitel yöntemler, motivasyonla ilgili önceki araştırmalara ek görüşler sağlamıştır. Video oyunları konusundaki önceki motivasyon araştırmalarında belirlenen 5 yapıya (uğraş1, merak, kontrol, fantezi ve tercih) ek olarak 10 motivasyon öğesi, oyunu deneyimleyen 20 çocukla yapılan görüşmeler ve gözlemlerin çözümlemesinden ortaya çıkmıştır. Bunlar kimlik sunumu, sosyal ilişkiler, oynama, öğrenme, başarı, ödüller, çevreleyen bağlam, benzersizlik, yaratıcılık ve bağlam'dır.

Anahtar $\quad$ Bilgisayar oyunlarl, Video oyunları, Motivasyon, Öğrenme, Eğitim

Citation:

Tüzün, H., Barab, S.A., \& Thomas, M.K. (2019). Reconsidering the motivation of learners in educational computer game contexts. Turkish Journal of Education, 8(2), 129-159. https://dx.doi.org/10.19128/turje.546283 


\section{INTRODUCTION}

Even the most elegantly designed educational software will fail if the learners are not motivated to learn. For this reason, designers of any educational software must work to establish a context that learners will find motivating. Motivation is related to learning because learning is an active process that requires conscious and deliberate effort (Bruner, 1960; Wlodkowski, 1986). Learners are simply unlikely to learn if they are not motivated to apply the necessary effort. In recent years, there have been extensive efforts towards building learning environments that provide motivational elements. In particular, some educators are examining the potential of computers and are using principles underlying the design of video games to establish rich learning contexts (Barab, Thomas, Dodge, Carteaux, \& Tuzun, 2005; Malone, 1980; Malone \& Lepper, 1987).

Prensky (2002, p. 6) argues that people play games because they think "the process of game playing is engaging." He explains why some games may prove more motivating than other educational contexts. The purpose of the designers of computer games is to keep the players engaged. They need their players to come back to the game, and players' doing so is a measure of designers' success. However, many view the purpose of education in general as not being to engage learners but to support the learning of specific content. To motivate players, designers of games use gameplay, which are all the activities and strategies employed in the game to sustain the engagement and motivation of its players. Understanding the strategies or elements of gameplay used by designers can provide rich insights for instructional designers who attempt to develop instructional contexts that support content understanding in engaging ways.

The work in this study builds upon research and a conceptual framework largely provided by Malone and Lepper's (1987) work (Tzeng, 2001). They developed a taxonomy of intrinsic motivation for learning based on four factors motivating the learner: challenge, curiosity, control, and fantasy. In addition to research conducted by Malone and Lepper, other researchers have studied the elements that make educational computer games motivating. For example, Cordova and Lepper (1996) examined the effects of contextualization, personalization, and choice in the learning process. Results indicated that for each of the three treatment strategies learners showed higher levels of intrinsic motivation. As a result, they were more deeply involved with the activities and learned more in a fixed period of time. They also showed higher perceived competence than learners in the control group. The learners using personalized version of the games, based on their backgrounds and interests, displayed higher gains in motivation, involvement and learning than the learners using non-personalized version of the games. Similarly, learners who were offered a choice showed greater increases in learning and motivation.

The studies that Malone and Lepper (1987) based their conclusions on utilized computer games that were developed in the 1980s. When compared to their more recent counterparts (Gee, 2003), these games had low audio and video fidelity, had relatively few multimedia elements, and generally did not include the utilization of cooperation. For example, the Darts game, one of the games used in the Malone and Lepper studies, utilized a screen in text mode that lacked color. In addition, as pointed out by Chen, Shen, Ou, and Liu (1998), Malone and Lepper (1987) studied computer games when most of these games were designed for single-user play and therefore lacked a multi-user component. For this reason, most of the factors they considered included individualistic factors.

Much of the research in motivation and educational computer games has had methodological shortcomings. The first important problem in this regard is researcher-determined variables. Chen et al. (1998) criticized Malone and Lepper's (1987) taxonomy for their lack of multi-user elements and offered the preset motivational factors of competition, collaboration, and recognition. The second important problem with these studies is that of data collection methodology. These studies employed survey methodology and the results came from questionnaires administered only once. The sustainability and 
persistence of human motivation cannot be explained with data collected in a single session. As Bandura (1986) points out, motivation for activities should be measured at different points in time so as to decrease the risk of misinterpreting short-term changes in motivation. The third important problem is the significance of novelty effect in these studies that offered computer games to learners and then measured learners' motivation immediately after these games were played. For this reason, the validity of the findings related to the factors that explain the motivation of users playing these games becomes questionable, especially from the perspectives of sustainability and persistence. As Garris, Ahlers, and Driskell (2002) indicated, initiating player engagement and sustaining it over time are different phenomena, and little is known about the latter. Additionally, after evaluating sixty years of research on motivation in education, Weiner (1990) concluded that restricting motivation studies of learning just on the part of the individual was a narrow focus. He highlighted "considering frameworks larger than the self" (p. 621) and put emphasis on thinking about further motivational constructs, "such as belongingness" (p. 621). He also added that there could be "many uncharted areas to incorporate" (p. $622)$ into motivational theories.

The purpose of this study was to identify the motivational elements of an educational multi-player online role-playing computer game while addressing the aforementioned methodological shortcomings. The methodological efforts were guided by the following research question: "What are the motivational elements of Quest Atlantis (QA), whether intrinsic or extrinsic, in terms of student-defined motivation?" Motivation is a hypothetical construct (Good \& Brophy, 1997; Martin \& Briggs, 1986) and its definition varies. For the purpose of this study, motivation is defined as individuals' showing their willingness to initiate and sustain participation in QA activities. Examples of QA activities are completing Quests (engaging curricular tasks), participating in synchronous and asynchronous discussions, joining guilds, building virtual structures, and signing up for QA jobs.

\section{Quest Atlantis}

Quest Atlantis is an educational computer game that immerses children ages 9-12 in a 3D, multi-user virtual environment for completing educational activities (see Figure 1). The purpose of the game is to save the mythical world of Atlantis from an impending disaster (Barab, Thomas, Dodge, Carteaux, \& Tuzun, 2005). According to the back story of the game, as Questers (learners playing QA) complete educational activities called "Quests," they help save Atlantis from this disaster. Leveraging strategies from online role-playing games, QA combines strategies used in the commercial gaming environment with lessons from educational research on learning and motivation. It allows users to travel to virtual places to perform Quests, talk with other users and mentors, and build virtual personae. Quests are engaging curricular tasks designed to be entertaining yet educational.

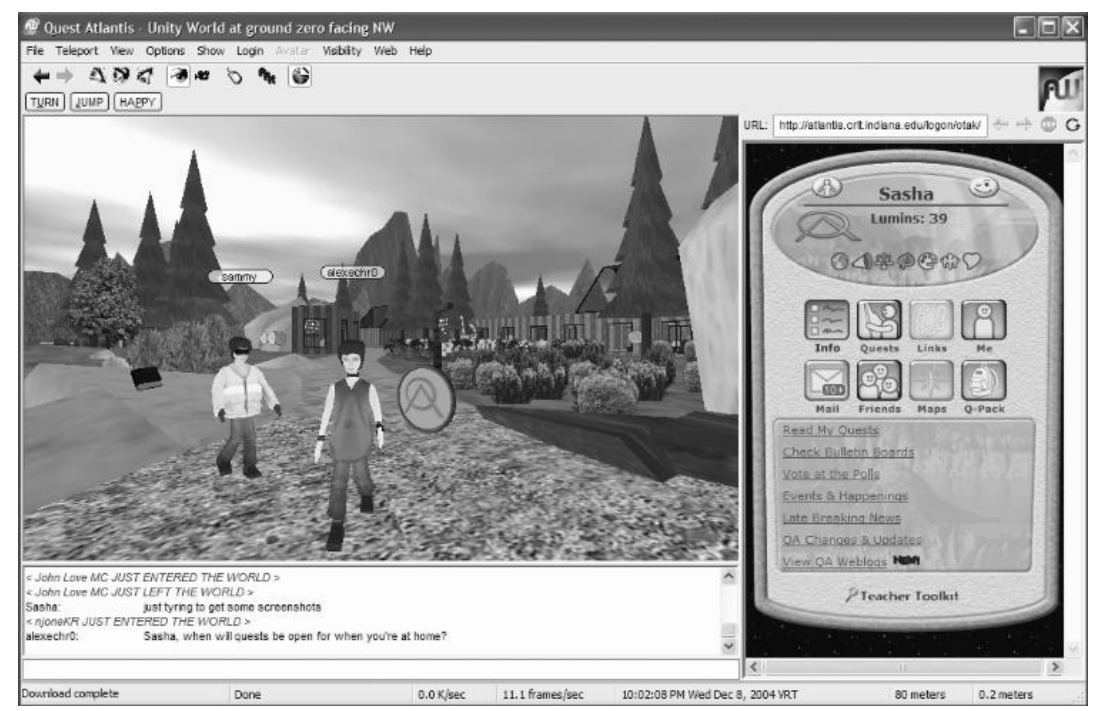

Figure 1. Screenshot of the virtual environment, showing the virtual environment on the left and the personal homepage of the player on the right. 
Quest Atlantis lies at the intersection of education, entertainment, and QA social commitments. However, instead of conceptualizing QA as computer software or a computer "game," it may be better described as a virtual environment designed to support an online community as well as multiple faceto-face communities. The Quest Atlantis storyline, its virtual worlds, and policies make up the Quest Atlantis meta-game in which there are numerous nested activities with an overlapping umbrella structure that gives the other activities structure. The Quest Atlantis meta-game contains the following key components: 1) a mythological legend that provides a back story for Quest Atlantis activities, 2) a number of 3D worlds and villages through which Questers, mentors, and the Quest Atlantis council members can interact with each other, 3) a Personal Digital Assistant (PDA) for each Quester, serving as a portfolio of their learning and participation, 4) an advancement system centered on pedagogically valid activities that encourage academic learning, entertainment, and social commitments, and 5) an extrinsic reward structure. Quest Atlantis has been implemented in different contexts, including schools as part of the curriculum through QA unit plans, and after-school programs as a volunteer activity (i.e., Boys and Girls Clubs of America).

The Quest Atlantis educational game provides a very different context from those games Malone (1980) and Malone and Lepper (1987) studied, and is quite different from games that were popular in the 1980s and 90s. QA attaches itself to the genre of computer games known as Massively Multi-Player Online Role-Playing Games (MMORPGs) in the commercial gaming sector. These games allow thousands of simultaneous users to synchronously collaborate on accomplishing particular game challenges. Most often, these games consist of a virtual world that players inhabit through the use of an avatar that can move around the space and perform actions. The avatar serves as sort of an alter ego or alternative identity whose actions are controlled by the player. Frequently, avatars have a certain look that is created by the player, and becomes a means of communicating one's game identity to others in the virtual space. As one can imagine, MMORPGs are very social places with members being able to form social groups, with some allegiances totaling over 200 members (Gee, 2003). This social element of MMORPGs as well as their users' ability to grow and project themselves through avatars serve as important motivators which were not readily available when Malone, Lepper, and colleagues did their initial motivation studies on gameplay.

As a multi-user virtual environment, QA has a three-dimensional environment that includes worlds and villages through which students navigate. At the time this study was conducted, there were 11 worlds each of which had a theme (e.g., Unity World, Culture World, and Ecology World). Each world had 3 villages addressing different aspects of the world's theme. It does this through the 20-25 Quests encountered in the village. A Quest lives inside of a village, and is an exercise or activity that Questers complete either in the virtual space or in the real world that allows them to investigate their world based on the village in which they are questing. Each Quest is connected to local academic standards and to underlying social commitments (e.g., environmental awareness, social responsibility, compassionate wisdom). Completing Quests requires that children participate in real-world, socially and academically meaningful activities, such as building personal scrapbooks, researching other cultures, conducting environmental studies, interviewing community members, calculating frequency distributions, and developing action plans.

Another important element of QA is the pro-social agenda that motivates participation. While QA does have a transgressive narrative in that the kids on Earth are trying to help the Council rebel against the corrupt leaders of Atlantis, they are doing so by adopting and advancing pro-social commitments focused on engaging what are typically adult-sanctioned behaviors. In this way, adults and society more generally acknowledge the child's behavior in QA as a valuable way to spend time. Additionally, and on a related note, QA has numerous opportunities to meaningfully participate in the QA community, such as signing up for jobs including link checker and greeter, or one can rent land and help to create and build the virtual environment itself. 


\section{METHODOLOGY}

This study can be characterized in multiple ways. It can be characterized as an example of ethnographic research since its purpose was to describe a culture-sharing group (Fetterman, 1998). Considerable amount of time was spent among the people at the selected research site (as documented in Barab, Thomas, Dodge, Newell, \& Squire, 2004; Barab et al., 2005). The study included common elements of ethnographic studies such as field work, participant observation, and interviews. This study can also be characterized as naturalistic (Lincoln \& Guba, 1985) because the data collection took place in a natural setting. Also, variables were not manipulated to confirm or disconfirm any a priori hypotheses.

Being the designers of this educational game complicates the authors' roles as researchers in this study in addition to those challenges traditionally associated with ethnography or naturalistic research (Clifford \& Marcus, 1986; Fielding \& Fielding, 1986; Silverman, 1993) because the researchers were more than participant observers. The philosophy of the QA implementation calls for collaboratively developing a vision for each of the implementation sites while this vision is researched at the same time it is created. Barab et al. (2004, p. 254) refer to this process as "design ethnography," referring to "an ethnographic process involving participatory design work with the agenda of transforming the local context while at the same time producing a design that can be used in multiple contexts." The goal of design ethnography can be described as changing or empowering the culture under study. During the process, individuals and local contexts transact in a manner that co-evolves the interlocutors. Design ethnography requires three ongoing focal points, which are trust, intervention, and sustainability. The evolution of QA took place during a 2-year ethnographic study, spanning the focal points of trust and intervention. This study took place during a timeframe in which the dominant focal point was the sustainability of the designed intervention.

\section{Context of the Study}

A purposeful sampling was conducted for the selection of the context. The following was the major criterion for identifying the context: Quest Atlantis centers that were enrolled in the QA program for at least six months and that would allow for ongoing information monitoring of behavior and frequent formal and informal interviews. This sampling criterion was used because a center was sought that went beyond the early adoption level (Rogers, 1995). In this way, any novelty effect was eliminated (Clark, 1983). In media studies, a novelty effect is an uncontrolled effect and tends to disappear over time (Krendl \& Broihier, 1991). As a result, this study took place in an after-school program located in a Midwestern town. The QA design and development team had been collaborating with this after-school program for over two years and the team had a fairly strong relationship with the program, making this a convenient sample location at which to carry out this research. Further, the fact that it was an afterschool context made it an interesting context for examining motivation in that learners were not compelled by teachers or traditional school structures and strictures to participate.

The after-school program was a member of the national Boys and Girls Clubs of America. There were 645 members between the ages of six and eighteen, of which $64 \%$ were boys and $36 \%$ were girls. Participation in the after-school program was voluntary and about 70 to 100 children participated on any given day. The club areas included the gym, game room, canteen area, teen room, library, art room, and computer lab. There were three full-time staff members for the general management including an executive director, a unit director, and a program director. Additionally, about fifty part-time staff members supervised children in all areas of the club. Children were transported from their schools to the club between $3 \mathrm{pm}$ and $4 \mathrm{pm}$ in a typical day. Once they were inside, it was up to them what to do during the rest of the day. They normally chose one of the routine activities in the areas mentioned. Children were picked up by their parents usually between $5 \mathrm{pm}$ and $6 \mathrm{pm}$. The closing time was $8 \mathrm{pm}$. 
The computer lab included 14 computers with broadband Internet connection, a file server, a flatbed scanner, and a laser printer. There were five part-time staff members to watch the lab. They worked on different days, and usually one to three staff members were present. The staff member with the most experience functioned as the lab manager and took care of the tasks such as setting weekly lab schedules, maintaining computers, and enforcing lab rules. The available software included the Windows operating system, the Microsoft Office Suite, Encarta Encyclopedia, various graphics software, Mavis Beacon Teaches Typing, Word Munchers Deluxe, Microsoft Magic School Bus educational software series, Reader Rabbit's Math, Amazon Trail, Civilizations, SimCity 2000, SimCity 3000, and Quest Atlantis. Use of these software and lab activities were scheduled weekly by the lab manager and advertised in the entrance to the lab.

\section{Participants}

The QA target audience is between the ages of 9 and 12. There were 346 members (54\%) within this range at the club, among which 133 members voluntarily signed up for QA. The interview participants were chosen conveniently from this group meeting the following criteria: (a) QA players, who had played the game on at least five different occasions; and (b) QA players, who had spent at least three hours within the game. With these criteria it was attempted that the Questers had accumulated the prerequisite skills necessary to play the game at a basic level. Based on these criteria, the first author was able to interview 20 children in the one-month timeframe anticipated for this task. Three of the interviewees also played QA at their schools. Children in the interview group attended the club 3.7 days a week on average $(\mathrm{SD}=1.6)$. As is typical of this Midwestern community, most interviewees were Caucasian Americans and just one of the children was African-American. Five of the children were female and fifteen were male. Typical of the low socio-economic status of children at this after-school context, fifteen of the children were from homes eligible for free or reduced lunch. These children used computers and the Internet for 3.5 years on average $(\mathrm{SD}=1.5)$. They used computers mainly for word processing, presentation, the Internet, and for games. Each one used the Internet at least once a week, while half of them indicated using it every day. In terms of games, half of them had a game console at home, three quarters mentioned games as a category of software they used on computers and half of them indicated playing games on the Internet.

\section{Data Collection}

Primarily ethnographic methods were used including interviews, observations in the different areas of the club with an emphasis on the computer lab, and document analysis. Semi-structured interviews were the primary method of data collection used in this study. As Fetterman (1998, p. 33) stated, "the ethnographer should ask the right questions" to provide validity for a research study. To ask the right questions, he suggested going into the field and finding out what people do in their daily lives. Aligned with this suggestion, two years of visits to the collection site preceded forming the questions asked during the interviews (see Appendix 1).

A total of twenty formal interviews lasting 15-45 minutes were completed over a thirty-six-day period. Transcription of the interviews resulted in 161 single-spaced pages of data. Observations were conducted primarily when members were interacting with QA in the computer lab. The first author typically spent five hours a day, Monday through Friday, from $3 \mathrm{pm}$ to $8 \mathrm{pm}$, in the computer lab for two months. Observation notes were entered into an online database and resulted in 76 single-spaced pages of data. The document analysis involved examining data from the QA servers, including all electronic data related to Questers' participation within the game.

\section{Data Analysis Procedures}

The constant comparison method of grounded theory was used for data analysis. Grounded theory is "... a general methodology of analysis linked with data collection that uses a systematically applied set of methods to generate an inductive theory about a substantive area" (Glaser, 1992, p. 16). In the 
constant comparison method, a method recommended for generating grounded theory, the researchers ask the following question while they continually code, compare, analyze, and write memos about the data while analyzing them: "What category or property of a category does this incident indicate?" (Glaser, 1992, p. 19). The categories inductively emerge out of the data rather than being decided prior to the data analysis (Patton, 1987). Possible data sources might include interviews, field observation records, documents, and video tapes (Strauss \& Corbin, 1994). Strauss and Corbin (1998) described three stages to analyze the data: (a) open coding, (b) axial coding, and (c) selective coding. The constantcomparison method was employed with the interview and observation records through these three stages. Since Weiner (1990) pointed out the "many uncharted areas to incorporate" into motivational theories, it was perceived that an inductive approach to data analysis was a suitable tool for illuminating these "uncharted areas." Aligned with this idea and consistent with the original work by Glaser and Strauss (1967), researchers resisted forcing their preconceptions on to the data as much as possible, and let the categories emerge from the data. For this reason, it can be said that the use of grounded theory and the constant comparative method in this study is closer to that of Glaser's $(1978,1992)$ in philosophy.

\section{Open coding}

The first five interview documents were open coded by the three authors, while the remaining fifteen interview documents were coded by the first and third authors. The same two authors coded one of the observation records. All of the remaining observation documents were coded by the first author. During the open coding, an answer to a question was coded as a whole paragraph. The researchers negotiated the codes until they arrived at $100 \%$ agreement. This process of open coding was independent of the research question. The open coding of the observation documents was conducted in a similar way and at the paragraph level. After the open coding of the interview documents, there were 202 codes. Open coding of the observation records added 32 new codes. A total of 234 codes were obtained.

\section{Axial coding}

In this stage categories were systematically developed. Open coding and axial coding were not sequential and researchers moved back and forth between the two stages, which occurred as part of the ongoing data collection process. The first and third authors preliminarily organized 234 codes in 16 categories. Further, these categories were collapsed then again under 5 of these original categories so as to create more parsimony and offer more usefulness to the codes: The "different from others" category included identity, social, building, and edutainment. The design category included homepage, 3D, and QA extras. The motivation category included store items and control. The implementation category included Boys and Girls Club context and people. The feelings category stood alone.

\section{Selective coding}

The three researchers then got together to discuss these categories and the codes within them. Since the open coding and the collapsing of categories were accomplished independent of the research question, these 16 categories and the larger 5 categories characterized the data well in general but did not characterize it well with respect to the research question; what were the motivational elements? For that reason, the researchers re-debated the codes and the categories in light of the data by using their own characterizations of motivation based on salient themes and the research question and by re-visiting the literature on motivation. This re-debate was a dialectic intersection of the categories grounded in the data, authors' intuitive responses to the research question, and existing theories of motivation.

After the re-debate, a number of changes were made. Nine of the categories were kept but renamed: building as creativity, social as social relations, identity as identity presentation, store items as rewards, motivation as achievement, 3D as immersive context, Boys and Girls Club context as context of support, different from others as uniqueness, and control as control and ownership. Six categories were dropped and they were collapsed under other categories: QA extras, people, homepage, design, implementation, 
and feelings. The remaining edutainment category was huge in size and therefore was split into playing and learning categories. Two new categories emerged that were previously nested under one of the 16 categories: curiosity and fantasy. In the end, thirteen categories were obtained all of which related to and were placed under the research question. These categories were: identity presentation, social relations, playing, learning, achievement, rewards, immersive context, fantasy, uniqueness, creativity, curiosity, control and ownership, and context of support.

In the findings section, these categories are presented in a way that has both experience-local meaning and at the same time is intended to have experience-distant significance (Geertz, 1973) to others analyzing motivation in different contexts and conditions. This occurs through ensuring that local interpretations are informed by and respond to previous research and theory, with presentations of the findings being contextualized in terms of the broader literature. Whereas there were over 1600 coded chunks of data within the 161 single-spaced pages of interview data, journal limitations have made it impractical to meaningfully immerse the reader into the local stories. Therefore, at least one chunk of raw data related to a category has been shared while spending much of the discussion of each of the 13 categories in terms of its meaning more generally.

\section{Trustworthiness}

Lincoln and Guba (1985) recommended using the word "trustworthiness" to refer to the notion of verification in qualitative studies. They defined trustworthiness as persuading the audience of a research study that the findings of the study are meaningful in terms of the empirical data. Triangulation has been a common method to provide trustworthiness in qualitative research (Bogdan \& Biklen, 1998; Patton, 1980). Denzin (1970) originally advocated the use of multiple methods and multiple sources of data to provide triangulation, while later suggesting using multiple researchers and multiple theories to improve triangulation (Denzin, 1978; Merriam, 1998). The first three approaches of triangulation were followed to increase the trustworthiness of this study. Multiple methods of data collection were used: Semistructured interviews, observations, and document analysis. Multiple sources of data were used: children using QA, personal observations, and QA participation information in QA electronic databases and logs. Finally, the three researchers participated in the constant comparative analysis of data.

\section{FINDINGS}

One indicator of motivation was the extent to which the 20 interviewees participated in QA activities. During the 14 months of use these Questers collectively logged on 1,594 times to the game $(M=80$, $S D=66)$, spent 583 hours within the game $(M=29, S D=34)$, and worked on 125 Quests $(M=6.3, S D=5.6)$, 88 of which were accepted by Quest response reviewers $(M=4.4, S D=4.3)$. Going through the constant comparison analysis of interview and observation data, thirteen motivational elements of QA were identified: (a) Identity presentation, (b) social relations, (c) playing, (d) learning, (e) achievement, (f) rewards, (g) immersive context, (h) fantasy, (i) uniqueness, (j) creativity, (k) curiosity, (l) control and ownership, and $(\mathrm{m})$ context of support. A discussion of these categories and the data illuminating the discussion are presented below. An advance organizer for them appears in Table 1. 
Table 1.

Thirteen Categories and Sub-Categories as Motivational Elements

\begin{tabular}{|c|c|c|c|c|}
\hline \multirow[t]{2}{*}{ Category } & Sub-category & $\begin{array}{c}\text { Number of instances } \\
\text { in interviews }\end{array}$ & \multicolumn{2}{|c|}{$\begin{array}{l}\text { Number of times coded in } \\
\text { interviews and observations }\end{array}$} \\
\hline & Avatars & 12 & 22 & \multirow{3}{*}{83} \\
\hline \multirow[t]{2}{*}{ 1. Identity Presentation } & Usernames & 5 & 10 & \\
\hline & Homepages & 18 & 51 & \\
\hline \multirow{7}{*}{ 2. Social Relations } & $\begin{array}{l}\text { Interaction with } \\
\text { others }\end{array}$ & 19 & 166 & \multirow{7}{*}{260} \\
\hline & Sharing & 10 & 40 & \\
\hline & Competition & 2 & 3 & \\
\hline & Showing off & 14 & 28 & \\
\hline & Groups & 10 & 13 & \\
\hline & Privacy & 2 & 5 & \\
\hline & Security & 4 & 5 & \\
\hline \multirow{3}{*}{ 3. Playing } & Multimedia & 4 & 5 & \multirow{3}{*}{147} \\
\hline & Points & 19 & 138 & \\
\hline & Pushball & 3 & 4 & \\
\hline \multirow{6}{*}{ 4. Learning } & Unique learning & 3 & 4 & \multirow{6}{*}{288} \\
\hline & $\begin{array}{l}\text { Meaningful } \\
\text { learning }\end{array}$ & 10 & 17 & \\
\hline & Active learning & 20 & 231 & \\
\hline & Feedback & 13 & 23 & \\
\hline & Multimedia & 4 & 5 & \\
\hline & Attitudes & 5 & 8 & \\
\hline \multirow{2}{*}{ 5. Achievement } & Challenge & 4 & 9 & \multirow{2}{*}{36} \\
\hline & Recognition & 18 & 27 & \\
\hline \multirow{4}{*}{ 6. Rewards } & Awards & 6 & 9 & \multirow{4}{*}{269} \\
\hline & Points & 20 & 185 & \\
\hline & Trading cards & 4 & 7 & \\
\hline & Open market & 19 & 68 & \\
\hline \multirow{2}{*}{ 7. Immersive Context } & Support structures & 5 & 6 & \multirow{2}{*}{170} \\
\hline & $3 \mathrm{D}$ & 20 & 164 & \\
\hline \multirow{2}{*}{ 8. Fantasy } & QA myth & 6 & 19 & \multirow{2}{*}{31} \\
\hline & Council members & 7 & 12 & \\
\hline \multirow{3}{*}{ 9. Uniqueness } & $\begin{array}{l}\text { Unique } \\
\text { opportunity }\end{array}$ & 9 & 19 & \multirow{3}{*}{133} \\
\hline & $\begin{array}{l}\text { Different from } \\
\text { others }\end{array}$ & 9 & 16 & \\
\hline & QA vs. others & 18 & 98 & \\
\hline 10. Creativity & Building & 19 & 129 & 129 \\
\hline \multirow{3}{*}{ 11. Curiosity } & End of the game & 2 & 3 & \multirow{3}{*}{28} \\
\hline & Quest status & 2 & 5 & \\
\hline & Secret places & 8 & 20 & \\
\hline \multirow{2}{*}{ 12. Control and Ownership } & Control & 14 & 38 & \multirow{2}{*}{52} \\
\hline & Jobs & 8 & 14 & \\
\hline & $\begin{array}{l}\text { School vs. club } \\
\text { differences }\end{array}$ & 3 & 9 & \\
\hline 13. Context of Support & Username & 2 & 2 & 14 \\
\hline & Trading post items & 3 & 3 & \\
\hline
\end{tabular}

\section{Identity Presentation}

Overall, there were 83 coded chunks related to this category. Within QA, what gave identity meaning were avatars, usernames, and homepages. The existence of the individual in the game starts with an avatar: 
Researcher: Why do you get excited [in QA]?

Anthony: ... Because you get to, like, transform into a ball or, James (one of the avatars) or any person you want ...

For most starters of the game, changing and trying different avatars was the first practice they engaged in. After a while, they settled on a specific avatar. Learners primarily chose an avatar in alignment with their genders, consistent with the research findings that using avatars in inhabited virtual worlds is a type of projection or personification of the self (Dickey, 2000). Although some players have viewed the avatar as a chance to explore alternative identities (Turkle, 1995), this was not the predominant use of the participants in this study.

A second cue of identity was usernames. Most of the participants selected a username with which they identified. Users usually persisted more with a username than with an avatar. Donath (1998) expressed that using a name and signature were two of the most important indications of one's identity on the Usenet. In the case of QA, the usernames also functioned as one's signature. Learners used their usernames to sign their Quest responses and e-mail messages. To reveal more of their identities, learners used their homepages:

Researcher: What do you think about your homepage?

Emily: Um, it's cool, I guess 'cause people can learn about you.

Researcher: What are the things that you like on your homepage?

Emily: Um...how you can say what you like and what you can do.

Username, homepage, and the avatar of a person were synthesized into a unified identity. Based on the interview data, expressing such an identity was a reason for them to play and continue to participate in this game. Other presentations of identity were less explicit. For example, the way children greeted each other in the virtual environment and the types of activities they chose to engage. Additionally, as they constructed virtual structures on their virtual plots of land they further expressed personal preference and crafted a presentation of their identity in the space. The important point is that children invested time and energy to advance a particular online identity.

\section{Social Relations}

Overall, there were 260 coded chunks of textual data related to this category. Social relations included interacting with others, sharing, showing off, and forming groups. The communication modes in the game, ranging from chatting and e-mailing to telegramming, afforded players the opportunity to form different social relations:

Researcher: Why do you get excited [in QA]?

Anthony: ... you get to also chat on [QA] and the words pop above your head and if you need help on like, a quest, you can like, say, if you guys know where desert is, if they know they'll show you. And that's why it's so much fun and exciting.

Another aspect of social relations was sharing. By cooperating and helping other players with various game tasks, participants were well aware of the fact that helping others was a way of showing their experience. While helping others they also enhanced their understanding of these skills in the social context of the game. Participants commented that the existence of so many helpers in the game attracted more players to join the game. When "helping others" became a job in QA that children could apply for, four boys and one girl immediately signed up.

Showing off is a type of self-presentation (Lott, 1977). Bennett and Yeeles (1990) conducted research to uncover children's understanding of showing off. For this purpose, they asked the children what their peers showed off and why they thought their peers showed off. Related to the first question, researchers found references to possessions and associations and references to behavior. Related to the second 
question, the researchers found references to intrapersonal psychological determinants and references to interpersonal determinants. In the QA context, players showed off possessions like points, virtual buildings they constructed, and virtual trading cards they collected. They showed these off because they wanted to emphasize their game experience. Therefore, their showing off was for interpersonal reasons.

Observations revealed that children mostly preferred to play the game in groups instead of playing it individually. This is further supported by the fact that they gave a higher number of responses related to social relations than identity presentation. Here the importance of the peer groups needs to be conveyed. More than one fourth of the children interviewed indicated that they chose to play QA either because they saw other kids' playing QA, or heard other kids' talking about QA at the club. This triggered initial interest in trying the game:

Researcher: Why did you join Quest Atlantis?

Luke: Everybody says [it's a] pretty cool game so I wanted to see how good it was.

In his social learning theory, Bandura (1986) emphasizes the significance of observing and modeling the behaviors and attitudes of others. Such peer effects were also documented outside education. For example, Gladwell (2000) documents the impact of peer groups in the way Hush Puppies became a popular shoe brand.

One of the possible choices an individual could make in QA was to sign up as part of a larger group of Questers in a common guild. Over half of the children signed up for a guild, even without a firm structure for the guilds. This supports the notion that players wanted to be a part of a social group. Membership in this kind of group is considered a major reason for why many people remain in multi-player games even after they finish exploring the game world (Sellers, 2002; Steinkuehler, 2006).

The secure environment provided by the game had a very important role in nurturing all these social relations:

Researcher: So what are the things that you like on your homepage...?

Anthony: ... you can see the links. Like, if somebody is saying something bad, you can report on them...

QA provided flexibility for social relations while providing security. For example, learners were able to type anything in the chat area as long as what they wrote was not against the rules of the game community. In some other kid-friendly games, players do not have this flexibility and they need to chat by using a point-and-click system that lets them talk with other players by selecting canned phrases from a preset menu. Such a restrictive system in QA might weaken social relations in the name of security. In educational computer games, a secure environment should be provided to nurture the social relations, not to limit it.

\section{Playing}

Overall, there were 147 coded chunks of data related to this category. Learners considered QA as a game. Multimedia elements, points, and the pushball game contributed, to a great extent, to the game aspect of QA. Some other categories, like immersive context, creativity, or fantasy, were also considered as play elements.

Davies and Crowther (1995) point to the short term motivational effects of multimedia use in instructional products. While the novelty of multimedia elements may provide a short-term incentive to engage with the product, this does not ensure that students engage in the content and benefit from these elements towards learning. For this reason, using Herzberg's (Herzberg, Mausner, \& Snyderman, 1959) notion, they regard the multimedia features as hygiene factors; i.e. the presence of them does not motivate, but their absence demotivates. However, the use of multimedia elements in QA showed the opposite; graphics, sound, and animation provide motivation by making the product more game like. 
For example, the presentation of the back story through a cartoon-like animation contributed to the gameness of QA and at the same time consolidated the understanding of the fantasy, which is also a motivational category itself. Moreover, the audio narration of Quests and the option for Questers to hear the narration of the Quest texts in addition to being able to read them positively affected learning. This especially applied to those many learners who disliked reading or had difficulty with reading. The redundancy of narration and text together seemed to enhance learning, as suggested by Lee and Boling (1999), as evident in the following comment from one of the children:

Researcher: Tell me about activities you don't like to do in Quest Atlantis.

Tyler: To read the story thing. When you try to do the quest. But now I just, my friend [Mark], he just taught me how to make the words read it to me.

The use of points in QA added to its gameness. This is probably because most computer games include some kind of score keeping mechanism. Therefore, when learners noticed this mechanism in QA they perceived it as a game.

The third factor that makes QA game-like is activities such as the pushball game. These kind of games make the learning environment more interactive. In this way, in addition to inhabiting the game space, users can also interact with the objects in it. In the pushball game, players can interact with a large ball. When they score, the numbers on the scoreboard changes; therefore, they impact the environment. In a similar approach, Corbit (2002) utilized such an interactive game in a virtual world designed for teaching about science. Five of the children interviewed in this study were frequently observed playing pushball. This balancing of entertainment and educational activities has been central to the success of the project as an academic play space that meets the needs of children.

\section{Learning}

Overall, there were 288 coded chunks of data related to this category. While the components of multimedia elements, points, and pushball make QA game-like and make the learning fun, the fun part also comes from the learning itself. These Questers voluntarily worked on 125 Quests, all of which went through a process in which they were required to revise and improve their work. Given that children were free in this after-school environment to do whatever they wished as opposed to children using QA in school as required by a teacher, their voluntary choice to complete this many academic Quests was indicative of motivation.

When children submit Quests, they are then reviewed by a staff member posing as a Council member, and frequently the reviewer requires the child to revise the Quest if one wishes to receive credit. This feedback mechanism plays a major role in the Questers' learning process in addition to meaningful learning, active learning, and reflection. Dewey (1916/1966) points to the importance of trial and error in experiences; learners simply do something and when they fail they do something else until it works. In traditional learning environments this phenomenon is not recognized and learners are expected to perform above a standard in their first trial. Then their performances are graded and that experience is considered to be concluded. On the contrary, an experience that is improved over time seems to encourage learners to come back:

Researcher: So, you like questing, you like the council... and what else can you tell me?

Kevin: Yeah. Um also, when I make a mistake, I always like that because I like to read the letters that the council sends me if I made a mistake on my quest. I like to read those a lot.

Researcher: You like their feedback?

Kevin: Yeah.

Researcher: What they like and what you can improve on?

Kevin: Yeah. I like to read that 'cause it makes me feel like I could get better at doing it. 
It is apparent that learners enjoy learning through a game that educates them. Therefore, it can be suggested that play is an important element for learners and it should be combined with meaningful learning opportunities that require active participation to motivate them towards sustaining and completing these activities.

A learning approach that eliminates memorizing and is based on purposeful action and experience appear to be part of what makes learning meaningful in QA in that many of the children interviewed described their Quests as meaningful activity:

Researcher: If you compare Quest Atlantis with courses at the school, or with lectures, what do you think? Or with tests?

David: Tests? I think Quest Atlantis is a more learning thing. Because it teaches you about life, it teaches you about how you can treat others and about your neighborhood, what you can do, pick up trash and stuff, what you can do in the world when you get older instead of just teaching you. It still teaches you to something, like, to go on the web and learn about an artist. But, school doesn't teach you that kind of stuff.

Researcher: What do you think you learn at school?

David: Umm, I learn basically math and stuff like, writing stuff down and sentences. Stuff like that.

Learners in QA are provided learning opportunities that do not require memorizing. The Quests that they undertake still ask for disciplinary content knowledge; however, this knowledge is already provided to the learners through various resources. Accomplishing these Quests involves processing knowledge in a substantive manner like researching community problems, examining current events, conducting environmental field studies, writing autobiographical anecdotes, developing real-world action plans, producing advocacy media, and interviewing families and friends. Therefore, the materials are usable in learners' lives and they have meaning in the real-world.

One problem in making learning meaningful is the difficulty of doing so for many learners at once (Langer, 1997). This problem is overcome in QA by the diversity and flexibility of the Quests. For example, to accomplish a specific curricular goal, multiple Quests are offered to learners and in the after-school context they can choose which ones they wish to complete. Learners can choose one of these based on their experience, interest, or frequently because someone else completed this particular Quest. Bruner (1973) proposes that for education to be relevant to the learner, it should concentrate more on the unknown and be somewhat speculative. The learner should use the known and established for extrapolation. This philosophy requires migrating from being a "knower" to being a "seeker." Knowers value declarative statements and passive learning. Seekers, on the other hand, perceive them as an opportunity for speculation and doubt. In QA, the Quests encourage multiple views and emphasize that there are no right answers to a specific problem and they are presented as problems to be investigated rather than activities to be completed for a grade. This, in turn, discourages learners from providing static information and encourages active participation. The learners do not just read a problem and try to give a right answer to it. Instead they consult the resources to link their knowledge and provide sound responses to Quests from their perspective. Being a seeker in this process makes the learning active:

Researcher: How is [QA] different from the activities you do at home or at school? Like homework? Or other educational activities or games? Anything you can think of.

John: Yeah. Well, it's definitely different from homework. It's learning but it's fun learning. It's not just like, 'sit down and write' kind of learning. It's where you have to go and get stuff and find stuff. It's fun.

While emphasizing the importance of experience in learning, Dewey (1938/1963) points to the properties of that experience. It is the continuity of experience that nurtures learning. Continuity of experience suggests that the results of previous experiences are carried over to later experiences. Dewey $(1916 / 1966)$ states that reflection, "the discernment of the relation between what we try to do and what happens in consequence" (p. 144), in experience is important in providing this continuity. 
While reflecting on an experience, connections are established between what is done and its results. If the reflection part is separated from the active doing phase, the meaning and continuity of an experience is lost. Each Quest response in QA requires such reflection from the learners. Specifically, answering the Quests involves thinking about the following three reflection questions: 1) how does your response meet all the goals of the Quest? 2) what did you learn about the topic and yourself from doing this Quest? and 3) tell the council (of Atlantis) how your response helps the mission of QA. By answering these reflection questions, learners make their experience explicit. The experience is explained and understood. They discover the relationships between what they have done and the consequences of their actions. In this way, the whole experience is unified.

\section{Achievement}

Overall, there were 36 coded chunks of data related to this category. Most children liked completing the Quests. One of the main reasons for that is they perceived the Quests as a challenge. Observations, coupled with an examination of the Quests chosen, suggest that favorite Quests were the ones that were more challenging. The Quests which were difficult to find, which required collecting more information from resources, and which took more time to complete were the challenging Quests. Here is how one Quester defined Questing as a challenge:

Researcher: How is [QA] different from the Cartoon Network website?

Anthony: On Cartoon Network, there are so many games and on Quest Atlantis there's hardly any. All you can play is follow the leader or chase...

Researcher: What about questing?

Anthony: Questing is...not really a game it's...actually a challenge. It's kind of a game, but kind of not...

Likewise, activities like building and finding secret places were other challenges in QA. With these challenges some of the participants recognized that their skills and knowledge levels were improved. They enjoyed the achievement of overcoming these challenges:

Researcher: What is the most exciting thing you have done in Quest Atlantis?

Emily: Like, whenever I got the idea that I could make a party room, and everyone started coming to my house and looking at it. It really made me feel good.

Among the game challenges, helping the fictitious QA Council restore their lost knowledge emerged as a motivator for completing curricular tasks, at times taking precedence over getting points:

Researcher: Without the points, would you still do quests?

Mark: Yeah.

Researcher: What is the reason for that?

Mark: So you can help those people to build back their town.

The points were also an indicator of Questers' achievement. Points were used as a way to track one's development in the game. Since the points were accrued after completing educational tasks, ownership of more points meant further experience and development. This was evident in conversations among the Questers. For example, they differentiated between their overall score and their points available for spending and they called their overall score "experience points." Further, a few of them indicated the level they had achieved suggesting that the points and levels were perceived as an indicator of development and status. With points, their successes for handling challenges were recognized within the game:

Researcher: What do Quest Atlantis points mean to you?

David: A goal, because I did something and I got some points that I can spend. And I did a good thing so I get credit for it. 
Some users expressed that they felt that they had done a good job in completing Quests, specifically with tackling challenges. Therefore, they wanted to celebrate their effort and accomplishment with an object. For some, this was just keeping the points and looking at them. For others, it was getting some trading cards or another QA store item:

Researcher: ... Why do you care about those cards?

Amy: I care about them because, it's like, when you are working in a job, when you get your first paycheck, you have to go out and buy something with it. You are so proud of yourself because, that was your own money that you used to buy it. It's the same with if you use your own points to buy it. And it's really special.

\section{Rewards}

Overall, there were 269 coded chunks of data related to this category. In QA, the rewards are both materialistic and non-materialistic. Among the non-materialistic rewards are awards, points, and social approval. Among the materialistic rewards are items in the virtual trading post like trading cards, Internet time, pencils, rulers, and t-shirts. The availability of both kinds of rewards gives learners choice options for the outcome of their activities.

Awards are symbolic cups or trophies. There are seven kinds of awards in QA: health award, creativity award, agency award, diversity award, kindness award, environment award, and community award. These are given to the Questers after they exhibit exemplary behavior. These awards are displayed on the Questers' homepages. Although these are labeled as "awards" by design, participants also labeled them with different names such as trophy, metal, and badge.

Although there were varying opinions on the points, many children perceived them as an extrinsic motivator and completed the Quests to get some items. For example, one Quester described "the stuff" he could get as a reason for coming back to QA:

Researcher: Which parts of Quest Atlantis keep you coming back to Quest Atlantis? Eric: Probably the points and getting stuff. Mostly.

The available items they could earn were cardholders, Internet time, QA pencils, QA t-shirts, QA trading cards, QA rulers, and virtual land to build on. The place they can get these items is called "The OTAK Trading Post." It was observed that some kids checked its content daily to see if anything new was added. This is how one Quester described the trading post:

Researcher: What do Quest Atlantis points mean to you?

Anthony: The points mean that, uh, if you get enough points you can either get some cards, or if you even get enough and go to this one special place in the trading post, you can get Internet time, a pencil, just basically anything that gets listed there.

Among the material items, the QA trading cards emerged as one of the most valuable items kids wanted to obtain. Each village has cards that introduce famous people related to the theme of that village. For example, Jacques Cousteau is a famous ocean researcher and therefore he belongs to Water Village in the Ecoworld. In addition to a hand-drawn picture of the famous person, these colorful cards also include information about the person and less meaningful numbers and symbols so that Questers can assign them their own meanings as they trade cards with each other. A participant, who was observed as excited about collecting the QA cards, indicated that the QA cards also had educational value over their visual appearance:

Researcher: Why are you excited about cards?

Amy: Because I like getting new other people and it's just fun, because I usually don't collect cards like Pokémon, they are all boring. This is cool because like a famous person like Martin Luther King 
Jr., so you don't know who he was, like it tells about him. And I didn't know who [Florence] Nightingale was, and then I have her card and I know about this person.

It is not just the method of the distribution that is different from traditional learning contexts but also the nature of the materialistic rewards. These rewards have educational elements to a certain degree. QA trading cards are the best example of this educational element. While trading cards are extrinsic rewards, they are also educational at the same time. Therefore, they help in the creation of a recursive learning cycle.

One very interesting point about the rewards was the emergence of a liberal open market in QA. In this sense, learners perceive the QA points as a kind of exchange currency and use them for meaningful transactions. The points created a system through which they could make exchanges. For example, when they referred to getting the items from the trading post, most of them labeled that process as "buying" something. They indicated that items "cost" a certain number of points and labeled some items as "too pricey" or "expensive." When they did not have enough points to buy a certain item they said that they could not "afford" it. When there was no land in the Questers' building area, they said the Questers' building area was "sold out." There was even inflation in the game. They complained when the cost of a plot of land went from 6 points to 10 points. Similar to saving money in a bank, they saved up their points to buy items that were costlier. Overall, this exchange system seemed to create an order within the QA life. They completed the Quests, got points in return, and either saved those points for the future or spent them on different items. They adopted this system so firmly that one of them questioned how some structures of QA would function without such an exchange system:

Researcher: So if there were no points for doing quests would you still do the quests?

Kevin: Yes.

Researcher: And what would be the reason for doing that?

Kevin: So I could help rebuild the Arch. Also, if there were no points...well, I have one question. If there were no points, then how could you buy land?

\section{Immersive Context and Fantasy}

Overall, there were 201 coded chunks of data related to these categories. The immersive context of QA is provided by its support structures, 3D technology, QA myth, and council members. The support structures include QA posters, the QA activity chart, QA trading cards, the QA comic books, and a QA novel. These support structures extend the gameplay beyond the computers making the experience part of life. The QA opening video, comic books, and novels present the backstory of the game in alternative forms. This assures that the fantasy element of the game will be understood by many learners with different approaches to learning. This is how one of the learners used these support structures to learn about doing Quests:

Researcher: Can you describe for me which times [Quests] are hard to complete?

Luke: For example, I didn't know how to do it. But I figured it out.

Researcher: How did you figure it out?

Luke: The magazine gives you sometimes little clues.

Researcher: What kind of magazine is that? Are you talking about the teacher's manual?

Luke: No, the Quest Atlantis book.

Although the game was on a two-dimensional monitor, they talked about experiencing a space on the computer screen. In this space they were able to walk or run around and interact with other players through their avatar representations. Some called the feeling of being in this space as being "digital" some labeled it as the "virtual space." All in all, they felt as if they were part of this environment: 
Researcher: Why do you think [QA] is fun to play?

Sarah: Because, like, you get to do stuff, something like that, you don't get to do other things in there. It is like you are inside the computer.

Researcher: How is Quest Atlantis different than other games in the lab?

Sarah: It is different, because you get like, it feels like you are inside of it...

The visual representation in QA contributes to its immersiveness to a great degree. It is the possibility of navigation in 3D that feeds this immersive feeling. There are three forms of representation in semiotics: iconic, indexical, and symbolic (Woolley, 1992). A photograph of a house is an iconic representation, because the image carries some relation to the house it depicts. A house is the index of family, because it is a sign that carries a causal or sequential relationship to what it represents. A symbol has an arbitrary relationship with what it presents, like the word "house." If one were to define the navigation in the 3D space with one of these three semiotic representations this would not be possible, because it exceeds these three forms of representations. The experience of navigation in $3 \mathrm{D}$ itself is the representation. It does not require translation. A house in the game is a house which can be inhabited. Overall, 3D is motivating because it is naturally intuitive to players and the experience does not require representational translation. Tüzün et al. (2009) documented that such a 3D context is not only motivational but also functional by providing the affordances of exploration, interaction, collaboration, and immersion.

Although the feeling of the space in a computer game is natural for children and is motivating, a space is a space and nothing more than that. For example, remove the rides from an amusement park and you will have a space that loses its attractiveness. Similarly, what make the QA space attractive are the worlds, villages and structures that fill this space:

Researcher: What is the reason for that? Why do you like culture world? Tyler: Because there are all these different sculptures and stuff around ...

Furthermore, these fundamentals are not scattered in an arbitrary and loose manner but converged through a fantasy story: The People of Atlantis lost their knowledge and demand the help of earth children to restore their knowledge. Therefore, children are attracted to the game space, which is a matrix between Atlantis and Earth, and help Atlantians in restoring their lost knowledge by accomplishing Quests in the villages and the worlds:

Researcher: Can you explain more about why you complete quests?

John: ... I want to help the Atlantians ...

Herz (1997) argues that the computer game "Doom" was a very successful game not just because it used 3D technology, but because it also invoked the emotional feeling of horror in its players. Similarly, in QA, the altruistic motive of helping the people of Atlantis adds an emotional layer to the gameplay.

When reading a fictional novel or watching a fictional movie, the audience experiences two paradoxical feelings. On the one hand, most of the characters, places, or the stories described in novels or movies do not exist outside the pages of the novel or the screen of the movie theater. On the other hand, once the fiction is acknowledged, characters, places, or stories inside novels or movies are thought to have some sort of reality. When the novel or movie is over, the audience does not believe the characters, places, or story ends with it (Woolley, 1992). Likewise, the backstory of Quest Atlantis and its characters are considered as real by its players to a surprising degree. The possibility of the players' communicating with the characters of the story strengthens the realism of the fantasy:

Researcher: Are they hard to complete? The quests?

Ryan: It kind of depends. Some are hard and some are easy. One of them, it won't get accepted and I got a ton of help on it.

Researcher: Oh really? 
Ryan: Yeah, the person I was with, we went to all this extent making a PowerPoint presentation, and then Unidad [a council member] sent back a message saying, 'Oh, I like the pictures and everything but it needs more information,' and we took all the information we could find on the Internet.

Researcher: Did she mention a specific kind of information? What kind of information she was looking for?

Ryan: No. She said it was all good except I needed more information.

In the game design, there are other opportunities to interact with the council members in addition to Quest feedback. For example, when they break the rules they might be asked to send an apology. Here is how a Quester communicated with a council member when he used inappropriate language while chatting:

Subject: Apology

Dear Alim, I am very sorry for calling people dummies. I will not do this again.

\section{Uniqueness (Dissimilarity)}

Overall, there were 133 coded chunks of data related to this category. Although the dictionary meaning of the word uniqueness is "without an equal or equivalent" ("Dictionary.com-uniqueness," 2004), what authors are trying to conceptualize here is not the superiority of QA. Here the primary emphasis is the dissimilarity of this educational game from other educational games. Other educational games are also unique with their own characteristics, such as different learning opportunities, game characters, and such. For example, computer games on the Cartoon Network Web site were also unique to the interviewees of this study for the reason that they contained characters (such as Pokémon or Samurai Jack) and stories not available in QA, other games, or software. In terms of QA, the characteristics that made it dissimilar from other games were the opportunities it provided in the areas of learning, information technology, socializing, and creativity.

Half of the Questers interviewed perceived QA as a unique game which allowed them to do different tasks. The opportunities provided by the game were scattered among learning, using information technology, socializing, creativity, and the local context. This is how one Quester talked about these learning opportunities:

Researcher: Do you think you would not be able to learn this without Quest Atlantis?

Jason: Yeah, you probably could learn it. But maybe you wouldn't because you wouldn't get the chance.

Another Quester indicated that QA provided content and subject matter that was not taught at the school:

Researcher: For example, at the school, let's suppose you have Quest Atlantis. Would you learn through Quest Atlantis or would you learn through worksheet activities?

Kevin: I'd do both. 'Cause sometimes at school there's stuff that they don't teach on Quest Atlantis and on Quest Atlantis, there's sometimes stuff that they don't teach at school. So that's why I'd do both.

Overall, the synergy of all motivational elements contributed to the emergence of a unique game that is perceived by the learners as different from others. As an academic play space, QA offers students more than a game, more than traditional curriculum, and more than some list of rules. It unifies the ideas of learning, helping, and playing in ways that were not observed with other activities in children's lives (Barab, Arici, \& Jackson, 2005). Observations of these children suggest that this collective experience is unique in terms of other activities they experience. This uniqueness seemed to carry much cache in terms of its appeal to children. 


\section{Creativity}

Overall, there were 129 coded chunks of data related to this category. Creativity is defined as "the tendency to generate or recognize ideas, alternatives, or possibilities that may be useful in solving problems, communicating with others, and entertaining ourselves and others" (Franken, 1998, p. 354). According to Franken (1998), people are motivated to be creative because they need novel stimulation, they need to communicate their ideas and their values, and they need to solve their problems. It has been seen in most of the Quester interviews that children said that they like "creating stuff;" they like to be creative and they like to convert their ideas into reality.

Creativity requires an environment that is conducive to being creative. In this environment one must be challenged, be free, and have the time and resources that help with being creative (Fox \& Fox, 2000). QA provides these opportunities to its players. First of all, there is a separate game world, named "QVille," devoted to building activities. Once players rent a plot of land, they are free to build anything they want on this land. The challenge comes from the other builders in the neighborhood; by observing others' building activities they improve their own structures. This is how one Quester explained how the game allowed them to build with no constraints hindering their creativity:

Researcher: How is Quest Atlantis different from other things you do on the computer? You mentioned some other games. How is it different from other games, for example?

Kevin: Because they are...on other games there's no building stuff that you can build by yourself. Like, in Civilization II, you can only put stuff and you can only go to view and see it. You can't get around, because they only put it in certain place and I don't like that. But, in Quest Atlantis you can put your stuff in certain places and change it around and stuff. That's what I like about Quest Atlantis.

The building activities in QA not only allow spatial creativity but also imaginative creativity. For example, builders construct hotels, restaurants, and galleries for role-playing. Furthermore, some of them share these places with other players and assign one another rooms and roles in them. The literature supports that this kind of creative imagination can increase children's cognitive and social skills (Singer \& Singer, 1998). For example, an interesting collaboration emerged between two club Questers. One of them built a huge hotel building and the other built a restaurant. The two together designed these structures such that people would lodge in the hotel and eat in the restaurant.

It must be noted here that the building activities in QA were not structured around a curricular goal, and therefore it was in free play mode. In this free play mode, most of the players started their building activities with a house although this was not dictated or constrained. In traditional text-based shared environments, like MUDs and MOOs, the ability to build one's own room in the textual environment has been identified as crucial to the success of these environments (Schroeder, Huxor, \& Smith, 2001). All participants at the club who claimed a piece of land and built on it kept on paying the rent for it and building on it. These data suggest that the activity of building in the virtual space is a strong motivator for the learners to come back to the learning environment. Similarly, Osberg (1997) and Osberg et al. (1997) found that virtual world building activities were motivating for learners. The aforementioned popularity of creative building activities in QA was an early indicator of the impending interest towards construction-based sandbox digital environments such as Minecraft (Josef, 2016; Nebel, Schneider, \& Rey, 2016), which is massively popular among children in the last decade.

Although building activities were a significant creativity form in QA, one of the Questers commented on another creativity option. He suggested that Questers could create their own avatars:

Researcher: What can be added, for example, to make you get excited about that and whenever you are at the club, you will always want to come back [to QA]?

Mark: You can make your own dude (avatar) or something. Your guys that you can walk around and stuff. Like, you can build your own guy and walk him around. 
Based on this suggestion, the QA team developed an interface called the "Avatar Machine." Using this interface, Questers are able to "make" their virtual persona.

Another opportunity for creativity was in terms of how participants responded to the Quests. They spent much time choosing which Quests they wished to do, and then there was latitude in terms of how they would respond. For example, in one Quest that focused on building a scrapbook about one's community, students had a great deal of leeway in what information they used in their scrapbooks. We are reminded of one day in which a group of Questers were busily cutting out images from leftover magazines, with one local staff member walking in and stating, "When did the computer room become an art room?" When they were all completed, students took images of their work and uploaded them as part of their Quest responses. Other Quests provided similar opportunities for creativity as participants chose how they would respond to the particular Quests.

\section{Curiosity}

Overall, there were 28 coded chunks of data related to this category. There are two types of curiosity in QA also identified by Keller (1987) and Malone and Lepper (1987): Sources that address the senses of learners, and sources that address the cognition of learners. Secret places in game worlds and villages provide sensory curiosity and this is the prevailing source of curiosity in QA:

\section{Researcher: What makes Healthy World special?}

John: Healthy World...it's got a lot of secret places. That's what I like about a world.

The difference of this kind of sensory curiosity from the one described in the traditional sense needs to be examined. For Keller (1987) and Malone and Lepper (1987), sensory curiosity refers to the availability of color, sound, animation, and graphics. In QA, sensory curiosity reveals itself in the form of exploring. Players explore the game space to see what is available and also to find the secret places in it. Therefore, this type of curiosity is more than sensory and it blends into cognition. Players want to know what is available in the space and where the secret areas are.

Waiting for the feedback of Quest responses keeps learners in suspense and this is a type of cognitive curiosity. When a Quester submits a response for a Quest, the status of that Quest response is marked by the system as "pending." This means the Quest response was submitted and will be reviewed by a mentor soon. When it is reviewed and accepted, its status changes to "accepted." When the reviewer concludes that the response needs revision, the status of the Quest response changes to "revise." The status of all Quest responses can be reviewed by Questers on the "Quests" part of their homepages. During observations, two Questers (they were also interviewees) asked at separate times about the time it took to review the Quest responses. They stated that they were both curious as to whether their responses were accepted or not. Also, it was observed that after logging on to the game, most kids went directly to the "Quests" page to see the status of their pending Quests. However, if the learners do not obtain the feedback in a reasonable amount of time, this type of curiosity might end up with detrimental effects. Their expectation for the review time was around two days:

\section{Researcher: What is the least exciting thing you have done in Quest Atlantis?}

Rebecca: When it is like still pending, it is not very fun, because you want to know if you got it right or wrong.

Another source for cognitive curiosity is seeing the end of the game. In traditional games "Game Over" is recognizable by anyone who has some video game experience. Similarly, the purpose of adventure games is to solve a chain of puzzles to reach the end of the story. Since QA had a back story and it was similar to adventure games, they wanted to see the ending of the game:

Kevin: ...I'm always anxious, I'm always curious about what happens when you beat Quest Atlantis. 'Cause, like, when you do all the quests or you build the [wisdom of the arch] ... 
Researcher: If there were no items in the trading post would you still do quests to restore the lost Arch of Wisdom?

Kevin: Yeah. I would do quests for anything.

Researcher: What would be the reason for that?

Kevin: Because, um...I wonder what it looks like when it's all rebuilt. And um...I'm so curious about that.

However, the curiosity of seeing the end of the game has been less emphasized by learners among other sources of curiosity, which suggests that the curiosity sources related to the process of the gameplay is more engaging than the sources related to the product of the gameplay.

\section{Control and Ownership}

Overall, there were 52 coded chunks of data related to this category. The literature supports the importance of control over one's behavior for continuous motivation. For example, De Charms (1968) coined the terms "origin" and "pawn" to distinguish between activities that are accomplished freely and activities that are forced. When a person perceives that one's behavior is determined by a person's own choosing, the person is an origin. When the person perceives that behavior is determined by external forces, that person is a pawn. According to De Charms (1968) when people feel that they are the origins of their own actions this is a powerful motivational force directing future behavior.

Likewise, control over the game is a basic tension for learners. This tension of control is sensed in many dimensions. For example, they wanted to work on Quests that were not allowed. They wanted to use telegramming as a communication mode that was not supported by the designers. They wanted to use objects that were not available to them in their building activities. They wanted to buy their land instead of renting. And they wanted to have more than just one avatar choice in the ocean world. This tension creates a real dilemma for game designers. While designers need to provide playing and learning opportunities within the game, learners must have control over these opportunities so that they come back to this environment. In a similar fashion, the designers of Habitat, the first networked multi-user virtual world, recognized the importance of giving control to the users. However, they struggled on the level of power that should have been given to users (Morningstar \& Farmer, 1991). Their survey of the users of Habitat revealed that there were two kinds of users: those who valued anarchy, and those who liked management. A Quester who also played the game at his school stated that he was more likely to complete the Quests when he had control over the game:

Researcher: If you compare the implementation of $Q A$ in your class and at the club, what are the differences and similarities?

Thomas: Well the club, you get a lot more freedom. At school it is kind of do this, do that. You can still talk and stuff but at the club you can just do whatever you want. Sort of ... you know... talk to people, do quests. So at the club, I think I am most likely to do a quest or something.

When the control of the game was taken from them, the game was no longer enjoyable and became more of an obligation:

Researcher: Can you tell me about activities you don't like to do in Quest Atlantis?

John: Uh...well, there's really not that many. Its only when we're like, say, if you want to do something else on the computer and you're forced to do Quest Atlantis, that's the only real time that I really don't want to do Quest Atlantis. But that's the only thing.

Researcher: What is the difference between those times and times when you don't want to do it?

John: Because there are certain times that I really want to, say, check out my orbit zone [on the Cartoon Network Web site]. Or like, check out e-mail ... at those times Quest Atlantis is just not much of an enjoyment to me. It's more of like, a must. 
The conceptualization of control in this study is in accordance with Malone and Lepper's (1987) taxonomy of intrinsic motivation in that both recognize the importance of control. Here, however, the meaning of "control" was expanded to include both the tension of players and the dilemma of designers. In Malone and Lepper's (1987) taxonomy of intrinsic motivation, control is defined with three characteristics: contingency, choice, and power. The characteristic of contingency is acknowledged, and is apparent and requisite for control. Without user involvement or response, control cannot exist. This basic level is accomplished in QA by allowing players to direct their avatars, input Quest responses, and change information on their homepages. However, this basic level is not sufficient to draw players back to the game. What attracts users back to the game in terms of control is the plasticity or adaptability of game identification. In this sense, control is the ability of players to stretch or continually adapt game elements and rules. When learners accomplish this kind of control over the game, their sense of ownership over the game seems to increase. As a result, they come back to the game more often. An example of this is the creation of jobs. Within the game, Questers with certain experiences can apply for different jobs. These jobs include working at the help desk, working as a chat monitor, greeter, tour guide, engineer, link checker, and usability tester. When they complete the requirements of these jobs they earn points. There was no plan on the side of the design team to add such a participant structure to the game. However, the players pushed the game in such a direction to include it. Apparently, providing this kind of control requires interplay between players and designers.

Since the QA jobs idea came from the Questers, they tended to perceive jobs more like a responsibility instead of a chore. The initial user interface for the jobs had some usability problems. As a result, when they read that the "prior points" requirement for a job was twenty, they thought that they had to spend twenty points. For this reason, they saved their points towards getting a job. What is incredible about this is that these kids were willing to spend their points for working in the job even though they had to spend a lot of effort doing the job, which highlights the power of sharing the control with users.

\section{Context of Support}

The twelve categories mentioned so far impact the motivations of learners playing educational computer games. However, there is another category that impacts these twelve categories. This category is the context in which the educational game is played and therefore in which learning takes place. Other researchers have also recognized that motivation is influenced by the context in which learning takes place (e.g. Jarvela, 2001). There were three interviewees who played QA at their schools in addition to playing it at the club. With the help of data related to their QA use in their schools, three contextual differences emerged in terms of motivational categories. These differences were in the areas of control, identity, and rewards.

Since learners naturally need to participate in many activities, they have fewer opportunities to participate in the game at school. For this reason, a typical learner using QA at school spends one to two hours per week. Because of this limited usage, it appears that teachers strictly control the QA implementation to assure the experience is completed by all learners. For example, in one of the interviewees' classroom the teacher synchronized Questers' participation so that everybody was doing the same activity at the same time. Even after this kind of strategy, learners ended up with uncompleted Quests. A description of learners using QA at their schools revealed frustration over this control. The learners indicated that with increased control on the teachers' part, and decreased control on their part, their motivation to participate in the activities tended to decrease. At the club, learners had more time to participate in the activities. Also, their participation was less controlled by outside mentors.

A second contextual difference between the club and schools was in the assignment of usernames. At the club, Questers were free to pick any username they liked. In schools, some teachers tended to assign usernames to Questers, usually some combination of Questers' first names, last names, and some numbers. This is understandable from the viewpoint of teachers because this kind of strategy might help teachers with the organization of their classes. However, doing so may harm the identity of players and at the same time removes this empowering feature. 
The third contextual difference was in the diversity of rewards. The implementation of QA at the club included many more materialistic items in the trading post than the school implementations. Possibly, the addition and distribution of these rewards by teachers has been neglected because of time constraints or they were in conflict with the local culture. The culture, values, and norms of the context of the game implementation can make a difference in providing the motivational categories. More research needs to be done in broader contexts in order to illuminate the extent to which the implementation of motivational categories differs in other contexts.

\section{DISCUSSION and IMPLICATIONS}

Traditionally, research regarding motivation in computer games has characterized motivation in a smaller number of intrinsic categories, usually challenge, curiosity, control, fantasy, and choice (Cordova \& Lepper, 1996; Malone \& Lepper, 1987). A broader range of categories that motivated children in QA emerged as a result of this study. The study revealed a large set of interactive processes and proposed various categories to provide a broader explanation of human motivation.

Bandura (1986) acknowledged that "any theory of motivation must consider a large set of interactive processes if it is to provide an adequate explanation of human behavior" (p. 243). However, most motivation studies have focused on piecemeal factors to explain motivation, and traditionally theories of motivation have focused on just one, or a few, variables. The findings of this study point to multiple elements that contribute to one's motivation and these elements collectively constitute the construct of motivation. Ignoring most of these elements, and the interactions between them, while focusing on a few of them, could produce incomplete research results and possibly invalid conclusions. As the results of this study suggest, motivation is distributed among many elements of the context.

The identification of many new categories such as identity presentation, social relations, playing, learning, achievement, rewards, immersive context, uniqueness, creativity, and context of support was, in part, due to the unusual context of QA for learning. For example, identity presentation emerged as a motivator because of its affordance of allowing users to create and customize an avatar in this context. An immersive context emerged because of the support structures and the $3 \mathrm{D}$ engine of the game. Similarly, additional motivational elements emerged in part due to the unique socio-technical structures making up the game, shedding light on the importance of context. "One's notion of possibilities is very much constrained by actual particulars" (Barab, Arici, \& Jackson, 2005, p. 20). While Malone and Lepper's (1987) intrinsic motivational categories were useful in terms of the games they examined, designers need to acknowledge the restricting effects of particular contexts and products and need to consider how the particular aspects of a situation limit or facilitate the potential for motivating learners. The results of this study, in addition to expanding the conception of what motivates learners, further suggests that motivation may be contextually bound to the interactions possible due to the constraints of the context under study. Such a situative view challenges the notion that there exists a core set of internal categories that motivate all human action, instead suggesting that there are a number of factors and that different situations may engage more or less of these factors.

Considering that what motivation means and how it can be provided in a learning context will differ depending on the kind of learning philosophy one adopts, the findings of this study align most closely with the situative view, which acknowledges the individual-environment interaction. Instead of the clash of outside vs. inside, this view emphasizes the reciprocal character of the interaction through which individuals, as well as their cognition and motivation, are considered to be socially and culturally constructed. The core shift in this perspective is from the individual as the unit of analysis to the larger context through which one chooses to engage or not to engage in a particular activity (Barab \& Plucker, 2002). From this perspective, neither individuals nor environments are unmotivated or even 
maladaptive, but particular activities are motivating with respect to how it fits with individualenvironment.

This research on what motivates learners to participate in QA has provided us a host of motivational elements learners engaged in QA and that could be utilized by other educational games or technology projects. In QA, gameplay seems to be an important factor for providing sustained motivation over time. Many designers incorporate multimedia elements such as rich graphics, audio, video, animation, and color into games to provide motivation. It is true that these elements provide short-term novelty to motivate participation in educational games. However, once consumed, they do not keep the learners attached to the learning environment. For this reason, the gameplay must include other elements such as the thirteen categories that were identified in this research. Noticeable in Table 1 is the thickness of the social relations motivational category, which includes activities such as interacting with others, sharing, helping, and competing. The magnitude of the social relations category in the findings is parallel to the popularity of MMORPGs.

Research studies show that there is a decrease in school children's motivation as they progress through grades over time (Harter, 1981; Lepper, Sethi, Dialdin, \& Drake, 1996). Some scholars offered the use of extrinsic rewards as an answer to this question and this issue has created a hot debate among motivation researchers. Early studies conducted in the 1970's by Deci (1971, 1972), Kruglanski, Friedman, and Zeevi (1971), and Lepper, Greene, and Nisbett (1973) claimed the negative effects of extrinsic rewards on participants' successive intrinsic interest in the activities for which extrinsic rewards were no longer available. Another 100 additional follow-up research studies have been conducted and arrived at similar conclusions (Lepper \& Henderlong, 2000). Some other researchers, however, objected to this idea and their meta-analytical reviews claimed that such negative effects of rewards occur under certain conditions and, when properly arranged, rewards can be used to increase motivation (Cameron, Banko, \& Pierce, 2001; Cameron \& Pierce, 1994; Eisenberger \& Cameron, 1996). The opponents claimed that these meta-analyses were flawed, the conclusions were incorrect and these opponents came up with their own meta-analyses (Deci, Koestner, \& Ryan, 1999; Deci, Koestner, \& Ryan, 2001). They claimed, once again, that extrinsic rewards undermined intrinsic motivation.

While there are different viewpoints on the effects of the use of rewards on intrinsic motivation, the findings of this research is that multiple motivators, those that are intrinsic as well as extrinsic, can exist simultaneously for learning. Furthermore, these intrinsic and extrinsic motivators can exist and function simultaneously for the same activity. If "points" in the QA learning context are considered, for example, some of the learners indicated that they completed Quests in QA both to get points as well as to help the Atlantian people. Likewise, they collected points to buy extrinsic items but at the same time points showed their development. Furthermore, points acted as an exchange currency through which learners could make meaningful transactions in the QA context. Additionally, the element of points was perceived as a play element in this context and made the learning fun. In the traditional motivational research sense, one would assume that "points" would function as an extrinsic motivator. However, points in the QA context act as a complex and multi-featured motivator providing both intrinsic and extrinsic motivation.

\section{CONCLUSION and FUTURE WORK}

The results from this study are consistent with previous motivational research while at the same time offers an expanded description of what is motivating in the context of games. How these data relate to other games, other environments, or other contexts is not yet known. The data for this study were collected within an after-school context. In this sense, while playing with the educational computer game learners were not exposed to the limitations of traditional school contexts such as strict curricula and 
deadlines. It would be fitting to replicate this study in a school context with such constraints to investigate the extent to which the results match or differ. This is one of the ways to complement the motivational categories found as a result of this study.

This study carries the limitations which are inherent in qualitative studies. Among the most important of these limitations are the individual biases of the researchers and the complexities related to the generalizability of results. Since the researchers were members of the QA design team and therefore had substantial control over the design of QA, this study might have been influenced by the perceptions of the researchers. This is exacerbated by the fact that the researchers participated in QA activities in the computer lab of the selected center for more than two years. Therefore, many of the learners at the center had close connections with the researchers. Another limitation lies in the generalizability of the results to other contexts. The unique features of the setting under study, such as the young age group and participation in QA activities on a voluntary basis make it difficult to generalize. In addition, some of the game features, such as the QA being a "multi-player" game, make it even more difficult to generalize the results to all educational computer games. However, many researchers indicate that qualitative research is a way to describe unique social structures, and that "all social structures are unique" and therefore generalizability may not be a norm by which qualitative research should be judged (Schloss \& Smith, 1999).

Traditionally, studies examining the motivation of learners in games have typically relied upon quantitative methods, including one-time data collection through surveys. In addition, tasks whose meanings were not strategically aligned with the context were offered to measure motivation in most of these studies. The qualitative methods and the naturalistic context used in this study provided a very different perspective than what is available for understating what motivates learners in computer games. These results offer insight into the relationship between research contexts and theories advanced, and show the importance of conducting research in the context of naturalistic environments for evolving and advancing rich theories of motivation. We agree with Jackson $(1996$, p. 5) in that "for the most part human beings live their lives independently of the intellectual schemes dreamed up in academe, and that the domain of knowledge is inseparable from the world in which people actually live and act." Future studies should, therefore, consider doing research in naturalistic contexts for producing ecologically valid theories of motivation.

\section{Acknowledgement}

QA is based upon work supported by the National Science Foundation under Grant Nos. 9980081 and 0092831, and by the MacArthur Foundation. This article is a part of first author's dissertation study. 


\section{REFERENCES}

Bandura, A. (1986). Social foundations of thought and action: A social cognitive theory. Englewood Cliffs, IN: Prentice Hall.

Barab, S. A., Arici, A., \& Jackson, C. (2005). Eat your vegetables and do your homework: A design-based investigation of enjoyment and meaning in learning. Educational Technology, 45(1), 15-21.

Barab, S. A., \& Plucker, J. A. (2002). Smart people or smart contexts? Cognition, ability, and talent development in an age of situated approaches to knowing and learning. Educational Psychologist, 37(3), 165-182.

Barab, S. A., Thomas, M. K., Dodge, T., Carteaux, B., \& Tuzun, H. (2005). Making learning fun: Quest Atlantis, a game without guns. Educational Technology Research and Development, 53(1), 86-107.

Barab, S. A., Thomas, M. K., Dodge, T., Squire, K., \& Newell, M. (2004). Critical design ethnography: Designing for change. Anthropology and Education Quarterly 35(2), 254-268.

Bennett, M., \& Yeeles, C. (1990). Children's understanding of showing off. Journal of Social Psychology, 130(5), 591-596.

Bogdan, R. C., \& Biklen, S. K. (1998). Qualitative research for education: An introduction to theory and methods (3rd Ed.). Needhan Heights, MA: Allyn \& Bacon.

Bruner, J. S. (1960). The process of education. Cambridge, MA: Harvard University Press.

Bruner, J. S. (1973). The relevance of education. New York, NY: Norton.

Cameron, J., Banko, K. M., \& Pierce, W. D. (2001). Pervasive negative effects of rewards on intrinsic motivation: The myth continues. The Behavior Analyst, 24, 1-44.

Cameron, J., \& Pierce, W. D. (1994). Reinforcement, reward, and intrinsic motivation: A meta-analysis. Review of Educational Research, 64, 363-423.

Chen, G. D., Shen, G. Y., Ou, K. L., \& Liu, B. J. (1998). Promoting motivation and eliminating disorientation for web based courses by a multi-user game. Proceedings of World Conference on Educational Multimedia, Hypermedia and Telecommunications 1998(1), 1-7. (ERIC Document Reproduction Service No. ED 428 657)

Clark, R. E. (1983). Reconsidering research on learning from media. Review of Educational Research, 53(4), 445459.

Clifford, J., \& Marcus, G. (Eds.). (1986). Writing culture: The poetics and politics of ethnography. Berkeley, CA: University of California Press.

Corbit, M. (2002). Building virtual worlds for informal science learning (scicentr and scifair) in the active worlds educational universe (AWEDU). Presence: Teleoperators \& Virtual Environments, 11(1), 55-67.

Cordova, D. I., \& Lepper, M. R. (1996). Intrinsic motivation and the process of learning: Beneficial effects of contextualization, personalization, and choice. Journal of Educational Psychology, 88(4), 715-730.

Davies, M. L., \& Crowther, D. E. A. (1995). The benefits of using multimedia in higher education: Myths and realities. Active Learning, (3), 3-6.

De Charms, R. (1968). Personal causation. New York, NY: Academic Press.

Deci, E. L. (1971). Effects of externally mediated rewards on intrinsic motivation. Journal of Personality and Social Psychology, 18, 105-115.

Deci, E. L. (1972). Effects of contingent and non-contingent rewards and controls on intrinsic motivation. Organizational Behavior and Human Performance, 8, 217-229.

Deci, E. L., Koestner, R., \& Ryan, R. M. (1999). A meta-analytic review of experiments examining the effects of extrinsic rewards on intrinsic motivation. Psychological Bulletin, 125, 627-668.

Deci, E. L., Koestner, R., \& Ryan, R. M. (2001). Extrinsic rewards and intrinsic motivation in education: Reconsidered once again. Review of Educational Research, 71(1), 1-27.

Denzin, N. K. (1970). The research act: A theoretical introduction to sociological methods. Chicago, IL: Aldine.

Denzin, N. K. (1978). The research act: A theoretical introduction to sociological methods (2nd ed.). New York, NY: McGraw-Hill.

Dewey, J. (1916/1966). Democracy and education: An introduction to the philosophy of education. New York, NY: The Free Press.

Dewey, J. (1938/1963). Experience and education. New York, NY: The Macmillan Publishing Company.

Dickey, M. D. (2000). 3D virtual worlds and learning: An analysis of the impact of design affordances and limitations in active worlds, blaxxun interactive, and onlive! traveler; and a study of the implementation of active worlds for formal and informal education. Dissertation Abstracts International, 60(08). (Publication No. AAT 9941313).

$\begin{array}{llllll}\text { Dictionary.com-uniqueness. } & \text { (2004). } & \text { Retrieved } & \text { January } & 5, & \text { 2004, }\end{array}$ http://dictionary.reference.com/search?q=uniqueness 
Donath, J. S. (1998). Identity and deception in the virtual community. In P. Kollock, \& M. Smith (Eds.). Communities in Cyberspace. London: Routledge.

Eisenberger, R., \& Cameron, J. (1996). Detrimental effects of reward: Reality or myth? American Psychologist, 51, 1153-1166.

Fetterman, D. M. (1998). Ethnography: Step by step (2nd ed.). Thousand Oaks, CA: Sage.

Fielding N. G., \& Fielding, J. L. (1986). Linking data. Beverly Hills, CA: Sage.

Fox, J. M., \& Fox, R. L. (2000). Exploring the nature of creativity. Dubuque, IO: Kendall/Hunt.

Franken, R. E. (1998). Human motivation (4th Ed.). Pacific Grove, CA: Brooks/Cole Publishing Company.

Garris, R., Ahlers, R., \& Driskell, J. E. (2002). Games, motivation, and learning: A research and practice model. Simulation \& Gaming, 33(4), 441-467.

Gee, J. P. (2003). What video games have to teach us about learning and literacy. New York, NY: Palgrave Macmillan.

Geertz, C. (1973). The interpretation of cultures. New York, NY: Basic Books.

Gladwell, M. (2000). The tipping point: How little things can make a big difference. New York, NY: Little, Brown and Company.

Glaser, B. G. (1978). Theoretical sensitivity: Advances in the methodology of grounded theory. Mill Valley, CA: The Sociology Press.

Glaser, B. G. (1992). Emergence vs forcing: Basics of grounded theory analysis. Mill Valley, CA: Sociology Press.

Glaser, B. G., \& Strauss, A. L. (1967). The discovery of grounded theory: Strategies for qualitative research. Chicago, IL: Aldine.

Good, T. L., \& Brophy, J. E. (1997). Looking in classrooms (7th ed.). New York, NY: Longman.

Harter, S. (1981). A new self-report scale of intrinsic versus extrinsic orientation in the classroom: Motivational and informational components. Developmental Psychology, 17, 300-312.

Herz, J. C. (1997). Joystick nation: How videogames ate our quarters, won our hearts, and rewired our minds. Boston: Little, Brown, and Co.

Herzberg, F., Mausner, B., \& Snyderman, B. B. (1959). The motivation to work (2nd ed.). New York, NY: John Wiley \& Sons.

Jackson, M. (Ed.). (1996). Things as they are: New directions in phenomenological Anthropology. Bloomington: Indiana University Press.

Jarvela, S. (2001). Shifting research on motivation and cognition to an integrated approach on learning and motivation in context. In S. Volet \& S. Jarvela (Eds.), Motivation in learning contexts: Theoretical and methodological implications (pp. 3-14). Amsterdam: Pergamon Press.

Josef, N. (2016). Minecraft and the building blocks of creative individuality. Configurations, 24(4), 471-500.

Keller, J. M. (1987). Development and use of the ARCS model of motivational design. Journal of Instructional Development, 10(3), 2-10.

Krendl, K. A., \& Broihier, M. (1991). Student responses to computers: A longitudinal study. Journal of Educational Computing Research, 8(2), 215-227.

Kruglanski, A. W., Friedman, I., \& Zeevi, G. (1971). The effects of extrinsic incentive on some qualitative aspects of task performance. Journal of Personality, 39, 606-617.

Langer, E. J. (1997). The power of mindful learning. Reading, MA: Addison-Wesley Publishing Company, Inc.

Lee, S. H., \& Boling, E. (1999). Screen design guidelines for motivation in interactive multimedia instruction: A survey and framework for designers. Educational Technology, 39(3), 19-26.

Lepper, M. R., Greene, D., \& Nisbett, R. E. (1973). Undermining children's intrinsic interest with extrinsic rewards: A test of the "overjustification" hypothesis. Journal of Personality and Social Psychology, 28, 129-137.

Lepper, M. R., \& Henderlong, J. (2000). Turning “play" into “work” and "work" into "play": 25 years of research on intrinsic and extrinsic motivation. In C. Sansone \& J. M. Harackiewicz (Eds.), Intrinsic and extrinsic motivation: The search for optimal motivation and performance (pp. 257-307). San Diego, CA: Academic Press.

Lepper, M. R., Sethi, S., Dialdin, D., \& Drake, M. (1996). Intrinsic and extrinsic motivation: A developmental perspective. In S. S. Luthar, J. A. Burack, D. Cicchetti, \& J. R. Weisz (Eds.), Developmental psychopathology: Perspectives on adjustment, risk, and disorder (pp. 23-50). Cambridge: Cambridge University Press.

Lincoln, Y. S., \& Guba E. G. (1985). Naturalistic inquiry. Newbury Park, CA: Sage.

Lott, B. (1977). Sex role ideology and the observed social behavior of children. Paper presented at the Annual Meeting of the Eastern Psychological Association, Boston, MA.

Malone, T. W. (1980). What makes things fun to learn? A study of intrinsically motivating computer games. Dissertation Abstracts International, 41 (05), 1955B. (UMI No. 8024707) 
Malone, T. W., \& Lepper, M. R. (1987). Making learning fun: A taxonomy of intrinsic motivations for learning. In R. E. Snow \& M. J. Farr (Eds.), Aptitude, learning and instruction: Conative and affective process analyses (pp. 223-253). Hillsdale, NJ: Lawrence Erlbaum Associates.

Martin, B. L., \& Briggs, L. J. (1986). The affective and cognitive domains: Integration for instruction and research. Englewood Cliffs, NJ: Educational Technology Publications.

Merriam, S. B. (1998). Qualitative research and case study applications in education: Revised and extended from case study research in education (2nd ed.). San Francisco, CA: Jossey-Bass Inc.

Morningstar, C, \& Farmer, F. R. (1991). The lessons of lucasfilm's habitat. In M. Benedikt (Ed.), Cyberspace: First steps (pp. 273-302). Cambridge, MA: MIT Press.

Nebel, S., Schneider, S., \& Rey, G. D. (2016). Mining learning and crafting scientific experiments: A literature review on the use of minecraft in education and research. Educ. Technology \& Society, 19(2), 355-366.

Osberg, K. M. (1997). Constructivism in practice: The case for meaning-making in the virtual world. Dissertation Abstracts International, 58(06). (Publication No. AAT 9736351).

Osberg, K. M., Rose, H., Winn, W., Hollander, A., Hoffman, H., \& Char, P. (1997). The effect of having grade seven students construct virtual environments on their comprehension of science. Paper presented at the Annual Meeting of the American Educational Research Association, Chicago, IL. Retrieved November 18, 2003, from http://www.hitl.washington.edu/publications/r-97-19/

Patton, M. Q. (1980). Qualitative evaluation methods. Beverly Hills, CA: Sage.

Patton, M. Q. (1987). How to use qualitative methods in evaluation. Newbury Park, CA: Sage.

Prensky, M. (2002). The motivation of gameplay or, the real 21st century learning revolution. On The Horizon, $10(1), 5-11$.

Rogers, E. M. (1995). Diffusion of innovations. New York, NY: Free Press.

Schloss, P. J., \& Smith, M. A. (1999). Conducting research. Upper Saddle River, NJ: Prentice Hall.

Schroeder, R., Huxor, A., \& Smith, A. (2001). Activeworlds: Geography and social interaction in virtual reality. Futures, 33(7), 569-587.

Sellers, M. (2002). Creating effective groups and group roles in MMP games. Retrieved December 14, 2003, from http://www.gamasutra.com/resource_guide/20020916/sellers_01.htm

Silverman, D. (1993). Interpreting qualitative data: Methods for analyzing talk, text, and interaction. London, Sage.

Singer, D. G., \& Singer, J. L. (1998). Fantasy and imagination. In D. P. Fromberg (Ed.), Play from birth to twelve and beyond: Contexts, perspectives, and meanings (pp. 313-318). New York, NY: Garland.

Steinkuehler, C. A. (2006). Massively multiplayer online videogaming as participation in a Discourse. Mind, Culture, \& Activity, 13(1), 38-52.

Strauss, A., \& Corbin, J. (1994). Grounded theory methodology: An Overview. In N. K. Denzin, \& Y. S. Lincoln (Eds.), Handbook of qualitative research (pp. 273-285). Thousand Oaks, CA: Sage.

Strauss, A., \& Corbin, J. (1998). Basics of qualitative research: Techniques and procedures for developing grounded theory (2nd ed.). Thousand Oaks, CA: Sage.

Turkle, S. (1995). Life on the screen: Identity in the age of the internet. New York, NY: Simon \& Schuster.

Tüzün, H., Yılmaz-Soylu, M., Karakuş, T., İnal, Y., \& Kızılkaya, G. (2009). The effects of computer games on primary school students' achievement and motivation in geography learning. Computers \& Education, 52(1), 68-77.

Tzeng, S. C. (2001). Optimizing challenges and skills in the design of an educational computer game and exploring adolescents' gaming beliefs. Paper presented at the meeting of the Association for Educational Communications and Technology Conference, Atlanta, GA.

Weiner, B. (1990). History of motivational research in education. Journal of Educational Psychology, 82, 616622 .

Wlodkowski, R. J. (1986). Motivation and teaching: A practical guide. Washington, DC: National Education Association.

Woolley, B. (1992). Virtual worlds: A journey in hype and hyperreality. Oxford, UK: Blackwell. 


\section{APPENDIX 1}

\section{Interview Questions}

\begin{tabular}{|c|c|}
\hline 1 & Why did you join Quest Atlantis? \\
\hline 2 & Which parts of Quest Atlantis keep you coming back to Quest Atlantis? \\
\hline 3 & How might Quest Atlantis be different in a way that will make you come back? \\
\hline 4 & What do you get out of playing Quest Atlantis? \\
\hline 5 & What do Quest Atlantis points mean to you? Do you care about getting points? \\
\hline 6 & Tell me about activities you like to do in Quest Atlantis. \\
\hline 7 & What are your top three favorite activities? \\
\hline 8 & Tell me about activities you don't like to do in Quest Atlantis. \\
\hline 9 & What are your bottom three favorite activities? \\
\hline 10 & What is the most exciting thing you have done in Quest Atlantis? \\
\hline 11 & What is the least exciting thing you have done in Quest Atlantis? \\
\hline 12 & How has Quest Atlantis changed your life? \\
\hline 13 & $\begin{array}{l}\text { How is Quest Atlantis different than other things you do on the computer? In the computer lab? } \\
\text { In school? At home? }\end{array}$ \\
\hline 14 & What do you think about the Quest Atlantis trading post? \\
\hline 15 & Which items are available in the trading post? Do you care about these items? \\
\hline 16 & Did you purchase any item from the trading post? Why did you get these items? \\
\hline 17 & What do you think about your homepage? \\
\hline 18 & What are the things that you like in your homepage? \\
\hline 19 & What are the things that you don't like in your homepage? \\
\hline 20 & Why do you complete Quests? Are they hard to complete? \\
\hline 21 & Tell me about your favorite Quests. \\
\hline 22 & Tell me about your favorite worlds and villages. \\
\hline
\end{tabular}




\section{TÜRKÇE GENIȘLETILMIŞ ÖZET}

Öğrenenler motive olmazlarsa, en zarif şekilde tasarlanmış eğitim yazılımı bile başarısız olur. Bu nedenle, herhangi bir eğitim yazılımının tasarımcısı, öğrenenlerin motive edici bulduğu bir bağlam oluşturmak için çalışmalıdır. Bilgisayar oyunu tasarımcılarının kullandığı stratejileri veya unsurları anlamak, içerik anlayışını ilgi çekici şekillerde destekleyen öğretim bağlamları geliştirmeye çalışan öğretim tasarımcılarına zengin bilgiler sağlayabilir. Eğitsel bilgisayar oyunlarındaki motivasyona yönelik araştırmaların çoğunun yöntemsel eksiklikleri mevcuttur. Bu çalışmanın amacı bu yöntemsel eksiklikleri ele alarak, eğitsel bir çok oyunculu çevrimiçi rol oynama bilgisayar oyununun motivasyonel öğelerini ortaya çıkartmaktır. Yöntemsel çabalar şu araştırma sorusu tarafından yönlendirilmiştir: "İster içsel ister dışsal olsun, Quest Atlantis'in motivasyonel öğeleri nelerdir?"

Quest Atlantis (QA), eğitsel etkinlikleri gerçekleştirmek için 9-12 yaş arasındaki çocukların üç boyutlu, çok kullanıcılı sanal bir ortamda bulunmasını sağlayan eğitsel bir bilgisayar oyunudur. QA uygulamasının felsefesi, uygulama alanlarının her birisi için ortaklaşa bir vizyon geliştirirken, bu vizyonun oluşturulduğu sırada araştırılmasıdır. Barab ve arkadaşları (2004, s. 254) bu süreci "tasarım etnoğrafyası" olarak adlandırmakta olup sürecin amac1 "yerel bağlamı dönüştürme gündemiyle katılımcı tasarım çalışmasını içeren etnografik bir süreci takip ederek çoklu bağlamlarda kullanılabilecek bir tasarım üretmektedir."

Araştırma bağlamının seçimi için amaçlı bir örnekleme yapılmıştır. Bunun sonucunda, bu çalışma ABD'de bir Ortabatı şehrinde bulunan bir okul sonrası programında gerçekleştirilmiş̧tir. QA hedef kitlesi 9-12 yaş grubudur. Bu aralıkta programda 346 üye (\% 54) bulunmaktaydı. Görüşme katılımcıları bu gruptan aşağıdaki kriterleri karşılayanlardan elverişli bir şekilde seçilmiştir: (a) oyunu en az beş farklı durumda oynayan QA oyuncuları; ve (b) Oyun içerisinde en az üç saat harcayan QA oyuncuları. Bu kriterlere dayanarak, ilk yazar bu görev için öngörülen bir aylık süre zarfında 20 çocukla görüşme gerçekleştirmiştir. Verilerin toplanması için temel olarak görüşmeler, bilgisayar laboratuvarına önem verilerek kulübün farklı alanlarında yapılan gözlemler ve belge analizi kullanılmıştır. Yarı yapılandırılmış görüşmeler, bu çalışmada kullanılan birincil veri toplama yöntemidir. Veri analizi için temellendirilmiş kuramın sürekli karşılaştırma yöntemi kullanılmıştır. Sonuç olarak, tümü araştırma sorusuyla ilgili olan on üç kategori elde edilmiştir. Bu kategoriler şunlardır: kimlik sunumu, sosyal ilişkiler, oynama, öğrenme, başarı, ödüller, çevreleyen bağlam, fantezi, benzersizlik, yaratıcılık, merak, kontrol ve bağlam. Bulgular bölümünde, bu kategoriler hem yerel deneyime (experience-local) yönelik olarak hem de farklı bağlamlarda ve koşullarda motivasyonu analiz eden başkaları için uzak deneyimler (experience-distant) sağlayacak şekilde sunulmaktadır (Geertz, 1973). Bu durum, yerel yorumların önceki araştırma ve kuramlar tarafından bilgilendirilmesinin ve bunlara cevap verilmesinin sağlanmasıyla; ek olarak bulguların sunumunun geniş bir literatür kapsamında bağlamsallaştırılmasıyla gerçekleştirilmiştir. Tek aralıklı 161 sayfalık görüşme transkripti içerisinde 1600'den fazla kodlanmış veri parçası bulunmakta olup, dergi sınırlamaları okuyucuyu yerel hikayelere anlamlı bir şekilde götürmeye engel olmuştur. Bu nedenle, bir kategoriyle ilgili en az bir ham veri parçası paylaşılmakla birlikte 13 kategorinin her birisinin tartışılması her bir kategorinin genel anlamı açısından gerçekleştirilmiştir. Bu çalışmanın güvenilirliğini arttırmak için üçgenleme yöntemi (triangulation) kullanılmıştır. Çalışmada çoklu veri toplama yöntemleri kullanılmıştır: Yarı yapılandırılmış görüşmeler, gözlemler ve belge analizi. Çalışmada birden fazla veri kaynağı kullanılmıştır: QA kullanan çocuklar, kişisel gözlemler ve QA elektronik veri tabanları ile log kayıtlarındaki QA katılım bilgileri. Son olarak, üç araştırmacı sürekli karşılaştırmalı veri analizine katılmıştır.

Bu çalışmanın bir sonucu olarak, QA'de çocukları motive eden daha geniş bir kategori yelpazesi ortaya çıkmıştır. Çalışma, çok sayıda etkileşimli süreci ortaya koymuş ve insan motivasyonunun daha geniş bir açıklamasını sağlamak için çeşitli kategoriler önermiştir. Bu çalışmanın sonuçlarına göre, motivasyon bağlamın birçok unsuru arasında dağılmıştır. Bu çalışmanın sonuçları, öğrenenleri neyin motive ettiği 
konusundaki anlayışı genişletmenin yanı sıra, bir araştırmadaki bağlamın kısıtlamaları nedeniyle motivasyonun kısıtlamalar doğrultusundaki potansiyel etkileşimlerle sinırlı olabileceğini ileri sürmektedir. Ödül kullanımının içsel motivasyon üzerindeki etkilerine ilişkin farklı görüşler olsa da, bu araştırmanın bulguları, içsel olduğu kadar dışsal olanların da öğrenme için eşzamanlı olarak bulunabileceğini göstermektedir. Dahası, bu içsel ve dışsal motivasyonlar bir etkinlik için aynı anda var olabilir ve işlev görebilir.

$\mathrm{Bu}$ çalı̧̧manın sonuçları, önceki motivasyon araştırmalarıyla tutarlılık sağlarken aynı zamanda, oyunlar bağlamında neyin motive edici olduğuna dair genişletilmiş bir açılkama sunar. Bu verilerin diğer oyunlarla, diğer ortamlarla veya diğer bağlamlarla olan ilişkisi henüz bilinmemektedir. Bu çalışmanın verileri bir okul sonrası bağlamında toplanmıştır. $\mathrm{Bu}$ anlamda, eğitsel bilgisayar oyunuyla oynarken ögrenenler, katı bir müfredat ve ödev iletim tarihleri gibi geleneksel okul bağlamlarının sınırlamalarına maruz kalmamıştır. Sonuçların ne ölçüde uyuştuğunu veya farklılaştığını araştırmak için bu çalışmayı okul bağlamlarında bu tür kısıtlamalarla tekrarlamak uygun olacaktır. $\mathrm{Bu}$, bu çalışma sonucunda bulunan motivasyonel öğeleri tamamlamanın yollarından birisidir.

Geleneksel olarak, öğrenenlerin oyunlardaki motivasyonlarını inceleyen çalışmalar, anketler aracılığıyla bir kereye mahsus veri toplama da dahil olmak üzere geleneksel olarak nicel yöntemlere dayanmaktadır. Ayrıca, bu çalışmaların çoğunda motivasyonu ölçmek için bağlamla stratejik olarak uyumlu olmayan görevler verilmiştir. Bu çalışmada kullanılan nitel yöntemler ve doğal bağlam, öğrenenleri bilgisayar oyunlarında neyin motive ettiğini anlamak için mevcut olandan çok farklı bir bakış açısı sağlamıştır. 